\title{
Spawning induction and fecundity of commercial native fish species from the São Francisco River basin, Brazil, under hatchery conditions
}

\author{
Fábio Pereira Arantes ${ }^{1}$, Yoshimi Sato ${ }^{2}$, Edson Vieira Sampaio ${ }^{2}$ Elizete Rizzo ${ }^{1}$, Nilo Bazzoli ${ }^{3 *}$ \\ ${ }^{1}$ Laboratório de Ictiohistologia, Departamento de Morfologia, Universidade Federal de Minas Gerais (UFMG), Belo Horizonte, Brasil \\ ${ }^{2}$ Estação de Hidrobiologia e Piscicultura de Três Marias, Companhia de Desenvolvimento dos Vales do São Francisco e Parnaíba, \\ (CODEVASF), Três Marias, Brasil \\ ${ }^{3}$ Programa de Pós-Graduação em Zoologia de Vertebrados, Pontifícia Universidade Católicade Minas Gerais, PUC Minas, Belo \\ Horizonte, Brasil; " Corresponding Author: bazzoli@pucminas.br
}

Received 11 April 2013; revised 21 May 2013; accepted 15 June 2013

Copyright (C) 2013 Fábio Pereira Arantes et al. This is an open access article distributed under the Creative Commons Attribution License, which permits unrestricted use, distribution, and reproduction in any medium, provided the original work is properly cited.

\section{ABSTRACT}

In order to exploit native fish species for aquaculture, basic parameters of artificial reproducetion and estimates of reproductive potential for this fish must be determined to improve hatchery success. We analyze seven Brazilian commercial fish. Spawning was induced using the hypophysation method, with injection of crude carp pituitary extract (CCPE). Characiformes species signaled the spawning time with behavioral alterations (usually circular movements). The time of oocyte extrusion varied from $5.3 \pm$ $0.3 \mathrm{~h}$ in Salminus franciscanus to $8.6 \pm 0.1 \mathrm{~h}$ in Prochilodus argenteus after the second CCPE injection. The greatest diameter of a vitellogenic oocyte was registered for $P$. argenteus (873.9 \pm $122.2 \mu \mathrm{m})$ and the smallest was for Pimelodus maculates $(465.4 \pm 36.3 \mu \mathrm{m})$. The diameter of vitellogenic oocytes was very similar among species belonging to the same family. The highest ROI values were registered for Prochilodus costatus $(27.0 \pm 3.5 \mu \mathrm{m})$ and $P$. argenteus $(23.4 \pm$ $3.7 \mu \mathrm{m})$, while the lowest values were found in Pseudoplatystoma corruscans $(4.6 \pm 0.9 \mu \mathrm{m})$ and $P$. maculatus $(6.0 \pm 1.3 \mu \mathrm{m})$. Absolute fecundity (number of oocytes released at spawning) was lowest in $P$. maculatus and highest in $P$. corrus- cans. Relative fecundity (RF) presented a high correlation ( $r=0.98$ to 0.99 ) with gonad weight, indicating high efficiency of spawning. The RF also presented a high correlation with body weight $(r=0.88$ to 0.97$)$ and total length $(r=$
0.86 to 0.92 ). The highest $\mathrm{RF}$ was registered for Leporinus obtusidens, and the lowest was for $P$. corruscans. Released fecundity had a negative correlation with the diameter of vitellogenic oocytes and with the height of the follicular cells, and a positive correlation with the thickness of the zona pelucida. These results indicate that the species studied herein are suitable candidates for aquaculture due to their reproductive and zootechnical characteristics.

Keywords: Spawning Induction; Fecundity; Oocyte; Neotropical Fish; São Francisco River

\section{INTRODUCTION}

In the São Francisco River of southeastern Brazil there are several commercial fish species including: the surubim (Pseudoplatystoma corruscans), the dourado (Salminus franciscanus), the curimatãs (Prochilodus argenteus and Prochilodus costatus), the piau-verdadeiro (Leporinus obtusidens), the mandi-amarelo (Pimelodus maculatus) and the matrinxã (Brycon orthotaenia). All of these species are "piracema" fish that is they perform reproductive migrations for spawning. When maintained in captivity or in lentic water, these species interrupt their reproductive cycle and do not reach the spawning stage [1]. The "surubim" reaches $180 \mathrm{~cm}$ and more than 100 $\mathrm{kg}$ and has great demand by consumers and farmers. The dourado is the most popular sport fish reaching $140 \mathrm{~cm}$ of length and $30 \mathrm{~kg}$ body weight. The curimatãs and the mandi-amarelo are the primary species captured by professional fisheries, with $P$. argenteus being the largest 
species (14 kg) among the Prochilodontidae [2]. The piau-verdadeiro is important for both professional and sport fisheries reaching $7.5 \mathrm{~kg}$. The matrinxã reaches 7 $\mathrm{kg}$ and is threatened with extinction in some regions of the São Francisco River [3]. All of these species utilized in this study are single batch spawners, have free oocytes, and lack parental care. Besides the large size of all these species, their meat has desirable organoleptic characteristics combined with a good carcass income, which makes them good candidates for aquaculture.

Along with the reduction of stocks of natural fisheries, there is an increasing need to develop artificial reproduction technology for high commercially valuable species in order to improve their reproductive potential and consequently the production of fingerlings for fish culture and reintroduction. Spawning induction in freshwater fish is usually performed using the hypophysation method [4], where crude carp pituitary extract (Cyprinus carpio) is injected into the coelomic cavity or within the muscle.

Fecundity is a reproductive strategy of fish that measures a species reproductive potential through the number of vitellogenic oocytes found inside the ovaries before the onset of the reproductive period [5-7]. Fecundity depends on body size, oocyte diameter, and spawning type and provides important information for aquaculture, fisheries management, and conservation [8,9]. Several measures of fecundity have been used for fish: total fecundity $[10,11]$, relative fecundity $[12,13]$, and actual fecundity $[14,15]$. Released fecundity is estimated through the number of oocytes released during a reproductive season by a single batch spawner [16] or in each egg lot released by a multiple batch spawner [17-19]. Released fecundity is also used for females submitted to artificial reproduction and is an indicator of spawn success.

In order to increase the knowledge of artificial reproduction and the reproductive potential of commercial fish, this work investigates seven species native to the São
Francisco River basin, Brazil, giving special attention to spawning induction by hypophysation and to fecundity.

\section{MATERIAL AND METHODS}

\subsection{Sampling}

For spawning induction, 409 specimens belonging to five species of Characiformes and two species of Siluriformes (Table 1) were captured in the São Francisco River at the region of the Três Marias dam $\left(18^{\circ} \mathrm{S}-20^{\circ} \mathrm{S}\right.$, $45^{\circ} \mathrm{W}-46^{\circ} \mathrm{W}$ ) in Minas Gerais state, southeastern Brazil. To capture fish were used gill nets and cast nets. The catch was performed by professional fishermen and the use of fishing boat. The fish were maintained for at least two years in tanks at the Hydrobiology and Fishculture Station of Três Marias, Minas Gerais-CODEVASF, Brazil, in densities of 0.1 to $0.2 \mathrm{~kg} / \mathrm{m}^{2}$. The fish feed was supplied in quantity only for their maintenance during the period of stocking, since analyzing the growth of the fish was not the objective of this work. The species $B$. orthotaenia, L. obtusidens, $P$. argenteus, $P$. costatus, and $P$. maculates were fed daily with commercial food $(36 \%$ crude protein) at the proportion of $1.5 \%$ to $2 \%$ live fish weight. The piscivorous species, $P$. corruscans and $S$. franciscanus, were fed live fish "ad libitum".

\subsection{Spawning Induction}

Females were selected for spawning induction according to external morphological characteristics, including a rounded coelomic cavity and reddish urogenital papillae. Specimens were measured, weighed, and maintained in hypophysation tanks with a continuous flow of water at an average temperature of $26^{\circ} \mathrm{C}$. Spawning induction was performed using the hypophysation method with injecttion of two doses of crude carp pituitary extract (CCPE) into the coelomic cavity. The first dose was of $0.6 \mathrm{mg}$ of

Table 1. List of species from the São Francisco River basin utilized in this study with total length (TL) and body weight (BW).

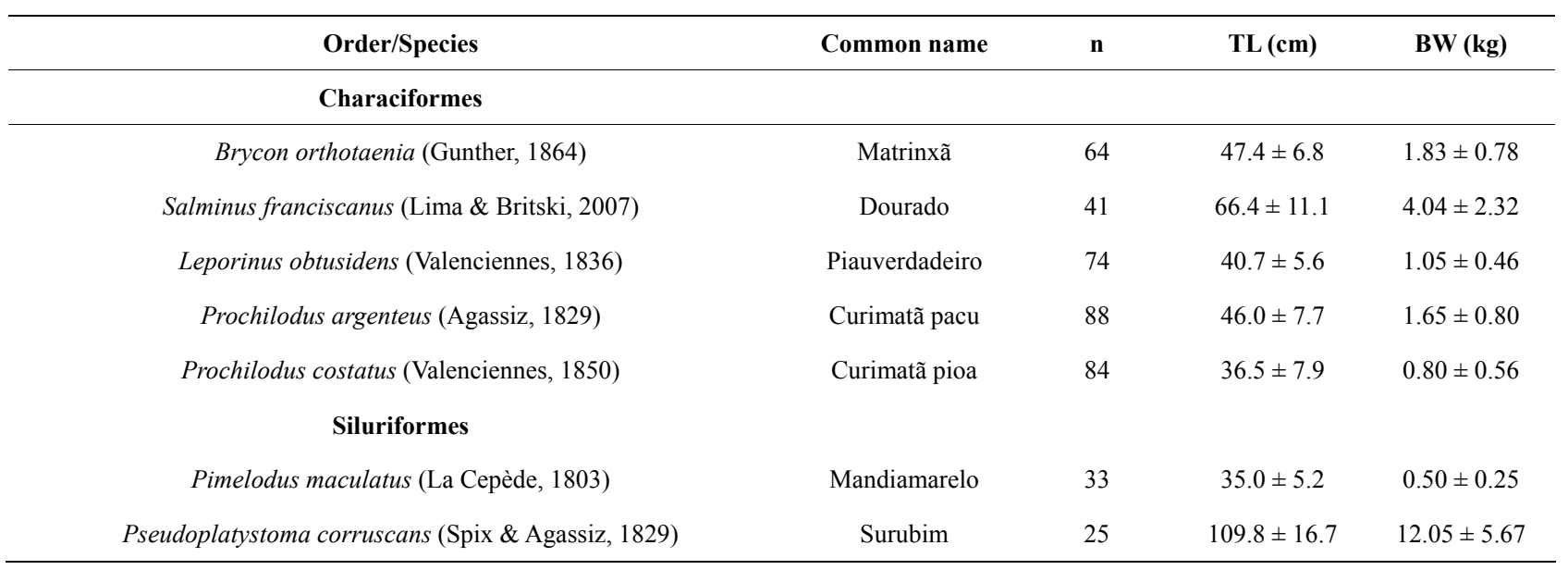

Data are expressed as mean \pm standard error (SE). 
CCPE $/ \mathrm{kg}$ body weight and the second dose was of 5.0 $\mathrm{mg}$ of CCPE $/ \mathrm{kg}$ body weight, and they were given with a time interval of 13 to 16 hours between doses (Table 2). Oocyte extrusion was performed by gentle pressure on the fish coelomic cavity. The time of extrusion for each species was determined considering the water temperature of $26^{\circ} \mathrm{C}$.

\subsection{Released Oocyte Index (ROI)}

Total length (TL), body weight (BW), and ova weight (OW-obtained by the weight of all released oocytes) were recorded for all specimens. These values were used to calculate the released oocyte index $(\mathrm{ROI}=100 \times \mathrm{OW} /$ BW).

\subsection{Histology}

In order to determine the diameter of vitellogenic oocytes, mature ovary fragments (three to five per species) were fixed in Bouin's solution and then submitted to routine histological techniques, embedded in paraffin and glycol methacrylate, cut in $4 \mu \mathrm{m}$ sections and stained with hematoxilin-eosine and/or toluidin blue-sodium borate.

The diameter of oocytes, the thickness of the zona pelucida, and the height of the follicular cells were measured using a micrometric ruler coupled to the ocular of a light microscope. For morphometricanalyses 50 oocytes in three histological sections of each species were used. Only complete spherical oocytes with little retraction were used for these measurements.

\subsection{Released Fecundity}

Samples of released oocytes $(0.5-1 \mathrm{~g})$ were collected, weighed, and fixed in modified Gilson solution $(100 \mathrm{ml}$ of alcohol $60 \%, 880 \mathrm{ml}$ of distillate water, $15 \mathrm{ml}$ of nitric acid $80 \%, 18 \mathrm{ml}$ of glacial acetic acid e $20 \mathrm{~g}$ of mercury chloride) in order to estimate released fecundity. Relative and absolute fecundities were determined considering: 1) ova weight (all released oocytes) (OW); 2) number of oocytes present in each ova sample; and 3) number of oocytes per gram of ova (NO/g). Absolute fecundity (AF) was determined by the number of oocytes per gram of ova and the total weight of the ova (all released oocytes) for each specimen and for each species $(\mathrm{AF}=\mathrm{NO} / \mathrm{g} \times$ $\mathrm{OW}$ ). To eliminate interference by fish weight on fecunddity estimation, the relative fecundity (RF) was calculated using body weight $(\mathrm{BW})$ through the expression: $\mathrm{RF}=\mathrm{AF} / \mathrm{BW}$.

\subsection{Statistical Analysis}

Pearson's correlation was used to correlate fecundity with body weight, total length, ova weight, vitellogenic oocyte diameter, height of the follicular cells, and thickness of the zona pelucida. The software GraphPad Prism 4 and Microsoft Excel were used for the analyses.

\section{RESULTS}

\subsection{Spawning Induction}

Response to spawning induction by hypophysation was satisfactory in all the species studied, with a success range of $64 \%$ to $80 \%$. The five Characiformes species ( $B$. orthotaenia, S. franciscanus, L. obtusidens, $P$. argenteus and $P$. costatus), signaled spawning time with behavioral alterations (usually circular movements) while the two Siluriformes species (P. maculatus and P. corruscans) did not show any signals. The time of oocyte extrusion varied from $5.3 \pm 0.3$ hours in $S$. franciscanus to $8.6 \pm 0.1$ hours in $P$. argenteus. The time for oocyte extrusion was in the same range in species of the same family such as $S$. franciscanus and B. orthotaenia of the Characidae, and $P$. argenteus and $P$. costatus of the Prochilodontidae (Table 2).

\subsection{Histology}

Vitellogenic oocyte diameter for the Characiformes

Table 2. Spawning induction parameters of species from São Francisco River submitted tohypophysation.

\begin{tabular}{|c|c|c|c|c|c|}
\hline Species & Spawning rate $(\%)$ & $\begin{array}{l}\text { Hours between } \\
\text { CCPE doses }\end{array}$ & Latency period $(h)^{*}$ & OSI (\%) & Fertilization rate $(\%)$ \\
\hline B. orthotaenia & 64.0 & $15.7 \pm 0.2$ & $5.5 \pm 0.1$ & $13.2 \pm 1.6$ & $55.83 \pm 9.02$ \\
\hline S. franciscanus & 64.0 & $15.7 \pm 0.7$ & $5.3 \pm 0.3$ & $11.9 \pm 1.2$ & $57.78 \pm 8.09$ \\
\hline L. obtusidens & 69.2 & $14.1 \pm 0.8$ & $8.2 \pm 0.1$ & $21.4 \pm 3.6$ & $70.36 \pm 8.39$ \\
\hline P. argenteus & 75.0 & $15.8 \pm 2.2$ & $8.6 \pm 0.1$ & $23.4 \pm 3.7$ & $73.03 \pm 8.51$ \\
\hline P. costatus & 80.0 & $16.5 \pm 2.3$ & $8.2 \pm 0.2$ & $27.0 \pm 3.5$ & $72.70 \pm 7.58$ \\
\hline P. maculatus & 70.4 & $14.3 \pm 0.7$ & $8.2 \pm 0.1$ & $6.0 \pm 1.3$ & $64.80 \pm 9.50$ \\
\hline P. corruscans & 66.7 & $13.1 \pm 0.4$ & $8.5 \pm 0.2$ & $4.6 \pm 0.9$ & $79.83 \pm 8.97$ \\
\hline
\end{tabular}

Data are expressed as mean \pm standard error (SE). Spawning rate $=$ percentage of females which ovulated after injection; ${ }^{*}$ period between second CCPE dose and oocyte extrusion; OSI $=100 \times \mathrm{OW} / \mathrm{BW}$. 
species varied from $558.0 \pm 57.2$ to $803.9 \pm 147.5 \mu \mathrm{m}$ while for the Siluriformes species it varied from $465.4 \pm$ 36.3 to $587.6 \pm 62.4 \mu \mathrm{m}$. The greatest vitellogenic oocyte diameter was registered in $P$. argenteusand the smallest in $P$. maculatus. Vitellogenic oocyte diameter presented very similar values among species belonging to the same family (Table 3).

The thickness of the zona pelucida of the vitellogenic oocytes varied among species, with the thickest in $P$. argenteus $(11.8 \pm 0.4 \mu \mathrm{m})$ and the thinnest in $P$. corruscans $(1.2 \pm 0.4 \mu \mathrm{m})$ (Table 3$)$.

All of the species analyzed had a single layer of follicular cells. The height of the follicular cells also varied among the species with the highest in P. maculatus $(27.4$ $\pm 7.3 \mu \mathrm{m})$ and the lowest in L. obtusidens $(1.5 \pm 0.4 \mu \mathrm{m})$ (Table 3).

\subsection{Released Oocyte Index (ROI)}

The highest ROI values were registered in the two Prochilodontidae species, $P$. costatus $(27.0 \pm 3.5)$ and $P$. argenteus $(23.4 \pm 3.4)$, while the lowest values were found in the two Siluriformes, P. maculatus $(6.0 \pm 1.7)$ and $P$. corruscans $(4.6 \pm 0.9)$ (Table 2$)$.

\subsection{Fecundity}

Absolute released fecundity was lowest in P. maculatus and highest in $P$. corruscans, with $91.78 \times 10^{3}$ and $1329.37 \times 10^{3}$ oocytes respectively (Table 4).

Relative fecundity (RF) presented a strong correlation with gonad weight, body weight, and total length (Table 5). The highest values of RF were found in L. obtusidensand the lowest in P. corruscans (Table 4).

\subsection{Pearson's Correlation Coefficient}

Vitellogenic oocyte diameter showed a negative correlation with the number of oocytes per gram $(r=-0.926)$ and with the height of the follicular cells $(r=-0.706)$, but a positive correlation with the thickness of the zona pellucida $(r=0.803)$. The height of the follicular cells showed a negative correlation with the thickness of the zona pellucida $(r=-0.831)$. Fecundity presented a positive correlation with thickness of the zona pellucida $(\mathrm{r}=$ $0.545)$, and a negative correlation with height of the follicular cells $(\mathrm{r}=-0.493)$.

\section{DISCUSSION}

Due to the scarcity of knowledge and technology regarding the culture of native fish species, Brazilian fish culture has mainly developed with exotic species. In order to exploit native fish species for aquaculture, basic reproductive parameters of native species have to be described, analyzed and incorporated into practice. In this context, artificial reproduction and the estimation of fecundity are of fundamental importance for the culture of commercial fish and for the conservation of threatened species. In the present study, all species had a satisfactory response to artificial reproduction and presented high fecundity.

The crude carp pituitary extract used in this study has been commonly employed in spawning induction proce-

Table 3. Mean \pm standard deviation of vitellogenic oocyte diameter (OD), zona pellucida thickness (ZP) and follicular cell height (FC) of species form the São Francisco River basin. Values are expressed as means \pm SD in $\mu \mathrm{m}$.

\begin{tabular}{cccc}
\hline Species & OD & ZP & FC \\
\hline B. orthotaenia & $683.2 \pm 90.6$ & $5.4 \pm 1.5$ & $4.1 \pm 1.2$ \\
S. franciscanus & $714.2 \pm 100.6$ & $7.3 \pm 1.4$ & $4.2 \pm 0.9$ \\
L. obtusidens & $558.0 \pm 57.2$ & $8.7 \pm 0.9$ & $1.5 \pm 0.4$ \\
P. argenteus & $873.9 \pm 122.2$ & $11.8 \pm 1.4$ & $2.3 \pm 0.4$ \\
P. costatus & $862.6 \pm 141.2$ & $11.4 \pm 2.0$ & $2.3 \pm 0.5$ \\
P. maculatus & $465.4 \pm 36.3$ & $2.3 \pm 0.6$ & $27.4 \pm 7.3$ \\
P. corruscans & $587.6 \pm 62.4$ & $1.2 \pm 0.4$ & $18.8 \pm 2.9$ \\
\hline
\end{tabular}

Table 4. Mean \pm standard deviation of the released oocyte weight $(\mathrm{OW})$, oocyte number per gram (NO/g), absolute fecundity (AF), relative fecundity (RF) and released oocyte index (ROI) of species from São Francisco River submitted to spawning induction.

\begin{tabular}{ccccc}
\hline Species & $\mathbf{O W}(\mathbf{g})$ & $\mathbf{N O} / \mathbf{g}$ & $\mathbf{A F}(\times \mathbf{1 0} \mathbf{3})$ & $\mathbf{R F}$ \\
\hline B. orthotaenia & $243.45 \pm 108.73$ & $1382.33 \pm 40.73$ & $337.55 \pm 152.47$ & $183.04 \pm 23.12$ \\
S. franciscanus & $475.80 \pm 266.95$ & $1221.80 \pm 73.24$ & $583.92 \pm 339.82$ & $145.92 \pm 18.66$ \\
L. obtusidens & $220.53 \pm 93.08$ & $2444.84 \pm 52.89$ & $538.03 \pm 223.12$ & $524.11 \pm 89.79$ \\
P. argenteus & $389.43 \pm 192.20$ & $1010.20 \pm 79.68$ & $397.46 \pm 206.87$ & $236.58 \pm 44.47$ \\
P. costatus & $212.29 \pm 147.02$ & $1206.65 \pm 119.05$ & $251.87 \pm 173.58$ & $324.47 \pm 48.20$ \\
P. maculatus & $28.05 \pm 14.5$ & $3258.76 \pm 144.95$ & $91.78 \pm 48.73$ & $180.78 \pm 25.66$ \\
P. corruscans & $532.52 \pm 212.79$ & $2499.32 \pm 63.21$ & $1329.37 \pm 527.36$ & $113.71 \pm 21.35$ \\
\hline
\end{tabular}


Table 5. Pearson's correlation coefficient (r) between the absolute fecundity (AF) and body weight (BW), total length (TL), and ova weight (OW) for species from the São Francisco River basin submitted to spawning induction.

\begin{tabular}{cccc}
\hline Species & $\mathbf{A F} \times \mathbf{B W}$ & $\mathbf{A F} \times \mathbf{T L}$ & $\mathbf{A F} \times \mathbf{O W}$ \\
\hline B. orthotaenia & 0.946 & 0.903 & 0.998 \\
S. franciscanus & 0.972 & 0.929 & 0.994 \\
L. obtusidens & 0.883 & 0.862 & 0.999 \\
P. argenteus & 0.920 & 0.900 & 0.987 \\
P. costatus & 0.974 & 0.898 & 0.983 \\
P. maculatus & 0.941 & 0.905 & 0.994 \\
P. corruscans & 0.895 & 0.891 & 0.998 \\
\hline
\end{tabular}

dures $[20,21]$. The time for oocyte extrusion in each species varies according to water temperature: the higher the temperature, the lower the time to the extrusion [1]. In this study the time for the oocyte extrusion was in the same range for species belonging to the same family, as observed by Sato et al. [22]. In summary, it can be considered that once the time to extrusion in a species is known, the values for other species belonging to the same family can be expected to be near this predetermined value.

The specimens belonging to the Characiformes showed behavioral alterations after the CCPE application, signalling the spawning moment (the signalling was demonstrated by circular or side to side movements). Behavioral alterations after hormonal induction were also observed by Andrade-Talmelli et al. [20] in Brycon insignis and by Dou et al. [23] in Anguilla japonica. On the other hand, the two species belonging to the Siluriformes did not present any evident behavior alteration as was also reported in the siluriform Pseudoplatystoma fasciatum [21].

Fish fecundity tends to increase with body size [24]. Consequently, in order to analyze fecundity data the effect of body size has to be eliminated. Several studies used the proportion between oocyte number and fish body weight or total length as relative fecundity [25]. Narahara et al. [26] and Stequert et al. [27] registered a high correlation between fecundity and gonad weight, as observed in this study, confirming the efficiency of the method used. Regarding the correlations between fecundity and body weight and fecundity and total length, fecundity showed a higher correlation with body weight, as observed by Rinne and Wanjala [28], Narahara et al. [26], Kjesbu et al. [10], Horwood [29], and Coward and Bromage [30], followed by total length, as was also observed by Bruch et al. [31]. Consequently, in this study relative fecundity was estimated using body weight. The absolute released fecundity presented lower values in $P$. maculatus and higher values in P. corruscans. This is probably due to the influence of body size since the relative fecundity of $P$. corruscans was the lowest of all the species analyzed.

Most teleosts release their gametes into the aquatic environment where fertilization and embryonic development occur. In this context the size and number of oocytes produced, as well as the number of times that oocytes are released in each reproductive period, are probably related to the environment where the eggs will develop [32]. According to Suzuki et al. [9], species that have reproductive migrations and do not display parental care, present higher fecundity values and smaller oocytes. This was also observed in this study where the species analyzed (all migratory and without parental care) presented high fecundity rates and small oocytes when compared to Loricariichthys platymetopon [9] non-migrating species that display parental care. The inverse relationship between the oocyte number and oocyte diameter observed in this study was also registered by Adebisi [33], Duarte and Alcaraz [34], Bromage et al. [35], and Suzuki et al. [9]. In this context, Bagenal [36] suggested that species with small oocytes have high fecundity as a reproductive strategy to compensate the low survival rate of larvae developed from small oocytes, as opposed to species with larger oocytes and low fecundity that produce larger larvae that have a better survival rate [37].

Egg incubation can also interfere with fecundity rates since species that have limited space available for incubation also have lower fecundity than species that spawn in ample spaces [38]. Thus, "tilapias" incubate their eggs and larvae inside their mouths [39] and possess low fecundity rates [30].

Adaptations found in fish eggs are countless. Among them stand out the adaptations related to structures that make the eggs fluctuating or adhesive and that allow the eggs to develop in environments with low oxygen content [25]. In this study, the thickness of the zona pelucida and of the layer of follicular cells, the main oocyte envelope, were analyzed. A negative correlation between oocyte diameter and the height of follicular cells was registered, while a positive correlation between oocyte diameter and the thickness of the zona pelucida was found. This is contrary to the observations of Suzuki et al. [9] in a study of six loricarid species, which have large and adhesive oocytes, reproductive strategies different to the species analyzed in this work.

The present study demonstrated that all of the species analyzed responded positively to spawning induction, with a high reproductive potential. Consequently, the results obtained provide important information about the artificial reproduction of freshwater teleost species in general, and thus making the studied species candidates for culture due to their reproductive and zootechnical 
characteristics.

\section{ACKNOWLEDGEMENTS}

This study was conducted with funds granted by CNPq, FAPEMIG and CODEVASF. We would like to also thank Dr. E. Wild for revising the English version.

\section{REFERENCES}

[1] Sato, Y., Fenerich-Verani, N. And Godinho, H.P. (2003) Reproduçã̃o induzidadepeixes da baciado São Francisco. In: Godinho, H.P. and Godinho, A.L., Eds., Águas e peixes no São Francisco das Minas Gerais, PUC Minas, Belo Horizonte, 275-290.

[2] Sato, Y., Fenerich-Verani, N., Verani, J.R., Godinho, H.P. and Sampaio, E.V. (1999) Reproductive traits of the yellow-mandi catfish Pimelodus maculatus Lacépède (Osteichthyes, Siluriformes) in captive breeding. Revista Brasileira de Biologia, 16, 981-986.

[3] Sato, Y. (1999) Reproduçã̃o depeixes da bacia do rio São Francisco: Induçã̃o e caracterizaçạ̃o depadrões. UFSCar, São Carlos.

[4] Woynarovich, E. and Horváth, L. (1980) The artificial propagation of warm-water finfishes-manual of extensions. FAO Fisheries Techinical Paper, Rome, 1-183.

[5] Bagenal, T.B. and Braum, E. (1978) Eggs and early life history. In: Bagenal, T., Ed., Methods of Assessment of Fish Production in Fresh Waters, IBP Handbook 3, Blackwell Scientific, Oxford, 165-201.

[6] Mazzoni, R. and Caramaschi, E.P. (1997) Spawning season, ovarian development and fecundity of Hypostomus affinis (Osteichthyes, Loricariidae). Revista Brasileira de Biologia, 57, 455-462.

[7] Vazzoler, A.E.A.M. (1996) Biologia da reproduçąå depeixesteleósteos: Teoria e prática. EDUEM, Maringá.

[8] Welcomme, R.L. (1967) The relationship between fecundity and fertility in the mouth brooding cichlid fish Tilapia leucosticta. Journal of Zoology, 151, 453-468.

[9] Suzuki, H.I., Agostinho, A.A. and Winemiller, K.O. (2000) Relationship between oocyte morphology and reproductive strategy inloricariid catfishes of the Paraná River, Brazil. Journal of Fish Biology, 57, 791-807.

[10] Kjesbu, O.S., Klungsøyr, J., Witthames, P.R. and GreerWalker, M. (1991) Fecundity, atresia, and egg size of captive atlantic cod (Gadus morhua) in relation to body composition. Canadian Journal of Fisheries and Aquatic Sciences, 48, 233 -2343. doi:10.1139/f91-274

[11] Kelly, C.J., Cowwolly, P.L. and Bracken, J.J. (1996) Maturity, oocyte dinamics and fecundity of the roundnose grenadier from the rockalltrough. Journal of Fish Biology, 49, 5-17. doi:10.1111/j.1095-8649.1996.tb06064.x

[12] Tyler, C.R., Pottinger, T.G., Santos, E., Sumpter, J.P., Price, S.A., Brooks, S. and Nagler, J.J. (1996) Mechanisms controlling egg size and number in the rainbow trout, Oncorhynchus mykiss. Biology of Reproduction, 54, 8-15. doi:10.1095/biolreprod54.1.8
[13] Fawole, O.O. and Arawomo, G.A.O. (2000) Fecundity of Sarotherodon galilaeus (Pisces: Cichlidae) in the Opa reservoir, Ile-Ife, Nigeria. Revista de Biología Tropical, 48, 201-204.

[14] Dickerson, T.L., Macewicz, B.J. and Hunter, J.R. (1992) Spawning frequency and batch fecundity of chub mackerel, Scomber japonicus, during 1985. Calif. Coop. California Cooperative Oceanic Fisheries Investigations Reports, 33, 130-140.

[15] Yamada, T., Aoki, I. and Mitani, I. (1998) Spawning time, spawning frequency and fecundity of Japanese chub mackerel, Scomber japonicus in the waters around the IzuIslands, Fisheries Research, 38, 83-89. doi:10.1016/S0165-7836(98)00113-1

[16] Óskarsson, G.J., Kjesbu, O.S. and Slotte, A. (2002) Predictions of realised fecundity and spawning time in Norwegian spring-spawning herring (Clupea harengus). Journal of Sea Research, 48, 59-79. doi:10.1016/S1385-1101(02)00135-1

[17] Kjesbu, O.S. (1989) The spawning activity of cod, Gadus morhua L. Journal of Fish Biology, 45, 719-735. doi:10.1111/j.1095-8649.1994.tb00939.x

[18] Trippel, E. 1998. Egg size and viability and seasonal offspring production of young Atlantic cod. Transactions of the American Fisheries Society, 127, 339-359. doi:10.1577/1548-8659(1998)127<0339:ESAVAS $>2.0 . C$ $\underline{\mathrm{O} ; 2}$

[19] Fordham, S. and Trippel, E. (1999) Fedding behaviour of cod (Gauds morhua) in relation to spawning. Journal of Applied Ichthyology, 15, 1-9. doi:10.1046/j.1439-0426.1999.00098.x

[20] Andrade-Talmelli, E.F., Kavamoto, E.T., Narahara, M.Y. and Verani, N.F. (2002) Reproduçã̃o induzida da piabanha, Brycon insignis (Steindachner, 1876), mantidaem cativeiro. Revista Brasileira de Zootecnia, 31, 803-811. doi:10.1590/S1516-35982002000400001

[21] Leonardo, A.F.G., RomagosA, E. Borella, I. and Batlouni, S.R. (2004) Induced spawning of hatchery-raised Brazilian catfish, cachara Pseudoplatystoma fasciatum (Linnaeus, 1766). Aquaculture, 240, 451-461. doi:10.1016/j.aquaculture.2003.11.030

[22] Sato, Y., Fenerich-Verani, N., Verani, J.R., Godinho, H.P. and Vieira, L.J.S. (2000) Reproductive traits of the neotropical anostomid fish Leporinus elongatus under hatchery conditions. Aquaculture Research, 31, 189-193. doi:10.1046/j.1365-2109.2000.00429.x

[23] Dou, S.Z., Yamada, Y., Okamura, A., Tanaka, S., Shinoda, A. and Tsukamoto, K. (2007) Observations on the spawning behavior of artificially matured Japanese eels $\mathrm{An}$ guilla japonica in captivity. Aquaculture, 266, 117-129. doi:10.1016/j.aquaculture.2007.02.032

[24] Wooton, R.J. (1990) Ecology of teleost fishes. Chapman and Hall, London, New York.

[25] Suzuki, H.I. 1998. Estratégias reprodutivas depeixes relacionadas ao sucessona colonizaçã̃o em dois reservatórios do rio Iguaçu, PR, Brasil. UFSCar, São Carlos (Tese, Doutorado em Ciências Biológicas).

[26] Narahara, M.Y., Godinho, H.M. and Romagosa, E. (1989) 
Tipodedesova e fecundidade do bagre, Rhamdia hilarii (Valenciennes, 1840) (Siluriformes, Pimelodidae). Boletim do Instituto de Pesca, São Paulo, 16, 37-45.

[27] Stequert, B., Menard, F. and Marchals, E. (2003) Reproductive biology of Vinceguerria nimbaria in the equatorial waters of the eastern Atlantic Ocean. Journal of Fish Biology, 62, 1116-1136. doi:10.1046/j.1095-8649.2003.00104.x

[28] Rinne, J.N. and Wanjala, B. (1983) Maturity, fecundity, and breeding seasons of the major catfishes (suborder: siluroidea) in LakeVitoria, east Africa. Journal of Fish Biology, 23, 357-363. doi:10.1111/j.1095-8649.1983.tb02915.x

[29] Horwood, J.W. (1993) Fecundity and biomass of plaice (Pleuronectes platessa L.) in the northern CelticSea. ICES. Journal of Materials Science, 50, 315-323.

[30] Coward, K. and Bromage, N.R. (1999) Spawning periodicity, fecundity and egg size in laboratory-held stocks of a substrate-spawning tilapiine, Tilapia zillii (Gervais). Aquaculture, 171, 251-267. doi:10.1016/S0044-8486(98)00498-0

[31] Bruch, R.M., Miller, G. and Hansen, M.J. (2006) Fecundity of lake Storgeon (Acipenser fulvescens) in Lake Winnebago, Wisconsin, USA. Journal of Applied Ichthyology, 22, 116-118. doi:10.1111/j.1439-0426.2007.00938.x

[32] Balon, E.K. (1975) Reproductive guilds of fishes: A proposal and definition. Journal of Fish Biology, 32, 821864.

[33] Adebisi, A.A. (1987) The relationships between the fe- cundities, gonadosomatic indices and egg sizes of some fishes of Ogun River, Nigeria. Archive fur Hydrobiologie, 111, 151-156.

[34] Duarte, C.M. and Alcaraz, M. (1989) To produce many small or few large eggs: A size-independent reproductive tactic of fish. Oecologia, 80, 401-404. doi:10.1007/BF00379043

[35] Bromage, N.R., Jones, J., Randall, C., Thrush, M., Davies, B., Springate, J., Duston, J. and Backer. G. (1992) Broodstock management, fecundity, egg quality and the timing of egg production in rainbow trout (Oncorhynchus mykiss). Aquaculture, 100, 141-166. doi:10.1016/0044-8486(92)90355-O

[36] Bagenal, T.B. (1969) The relationship between food supply and fecundity in brown trout Salmo trutta L. Journal of Fish Biology, 1, 167-182. doi:10.1111/j.1095-8649.1969.tb03850.x

[37] Mcdowall, R.M. and Eldon, G.A. (1997) Reproductive cycling and fecundity estimation in the upland bully, Gobiomorphus breviceps (Teleostei: Eleotridae). Journal of Fish Biology, 51, 164-179. doi:10.1111/j.1095-8649.1997.tb02522.x

[38] Blaxter, J.H.S. (1969) Development: Eggs and larvae. In: Hoar, W.S. and Randall, D.J., Eds., Fish Physiology (III). Reproduction a Growth, Bioluminescence, Pigments, and Poisons, Academic Press, New York, London. doi:10.1016/S1546-5098(08)60114-4

[39] Pinto, C.S.R.M. (1988) Criaçãa detilápias. Instituto de Pesca, São Paulo. 